\title{
REINSURANCE AND PERFORMANCE OF THE CEDING COMPANIES: THE NIGERIAN INSURANCE INDUSTRY EXPERIENCE
}

\author{
Sunday Adekunle ADULOJU', Sunday Stephen AJEMUNIGBOHUN ${ }^{2}$ \\ ${ }^{1}$ Actuarial Science \& Insurance Department, University of Lagos, Nigeria \\ ${ }^{2}$ Insurance Department, Lagos State University, Nigeria \\ Corresponding author e-mail: sunday.ajemunigbohun@lasu.edu.ng
}

\begin{abstract}
This paper examines the relationship between ceding office gross premium income, underwriting profit and financial stability. The study made use of primary and secondary data. The primary data were obtained from 246 respondents selected from those companies through the use of structured questionnaire. The secondary data obtained from the 2014 and 2015 published financials of the selected ten companies were used to determine the Reinsurance Ceded Ratio (RCR), Return on Asset (ROA), Return on Equity (ROE) as well as the Ratio of Reinsurance Recoverables to Policyholders Surplus (RRPHS). A descriptive research design was employed. The sampling technique adopted was purposive in nature. The study population comprises 56 insurance companies in Nigeria. More so, data collected was analysed using correlation analytical method. The results of this study are quite in line with previous studies and show that reinsurance purchase increases significantly the insurers' premium income. It is also shown that profitability of the firm is sensitive to change in reinsurance utilisation and has a positive relationship with it. It was established in the study that purchasing reinsurance reduces insurers' insolvency risk by stabilizing loss experience and increasing capacity. Recommendations were made.
\end{abstract}

Keywords: Ceding companies, insurance performance, reinsurance, reinsurance ceded ratio, return on asset, return on equity.

\section{INTRODUCTION}

Findings of many studies have made reference to the important role played by insurance in a nation's economy. In addition to its basic functions of risk pooling, spreading and loss indemnification, insurance is said to be a catalyst of economic growth by promoting long- term savings, encouraging accumulations of capital, and channelling those funds to productive investments (Fatula, 2007; Oluoma, 2014). One reason for a growing relevance of insurance is the role it plays in mitigating sudden and devastating occurrences that can cripple financially individuals and corporate organisations (Yinusa \& Akinlo, 2013). The availability of insurance services is essential for the stability of the economy as business organisations can take more risks in the course of their operations. In the developing economies, insurance is growing in importance due to its increasing share in the financial sector productivity (Oke, 2012).

In Nigeria, however, the level of insurance activities is said to be low with only $1.5 \%$ of the adult population having one form of insurance and other, given a large C2017 Sunday Adekunle Aduloju, Sunday Stephen Ajemunigbohun. This is an open access article licensed under the Creative Commons Attribution License (http://creativecommons.org/ licenses/by/4.0), in the manner agreed with De Gruyter Open. 
population of about 170 million and the huge volume of industrial and commercial activities (Rewane, 2015). One of the reasons for this low level of performance is the lack of adequate capital and capacity (Naidoo, 2010). It has been shown that a primary insurer can boost its underwriting capacity and reduce its financial exposure by ceding parts of its original risks to a reinsurer (Hall, 2010). Furthermore, in a study of Shah, Wilcox \& Alip, (2015), findings show that a strong-based market for reinsurance activities allows for solvency of insurance companies particularly in the event of high severity losses such as hurricane and plane crashes. Perhaps, in recognition of the importance of reinsurance in maintaining a virile insurance market, section 6 (c) of the Insurance Act 2003 ensures compulsory steps are taken by insurance companies in Nigeria to have a reinsurance arrangement in tangent with each class of insurance for transactions as parts of the requirements for registration.

In the modern times, risk-conscious individuals and organisations with highrisk profile seek adequate protection against the negative outcomes that may arise due to the presence of risk. Insurance company too, in order to reduce its heavy obligations, seeks to transfer part of its risk burden to other organisations, the reinsurers (Garven, Hillard \& Grace, 2014; Jirsarael, Kalantari, Kalantari, Jalah \& Nozari, 2013). According to Park \& Xie (2014), reinsurers are at the pinnacle of insurance market environment, because the abilities of reinsurers may bring about financial unrest within the insurance industry, which could result in spillover effect in the entire economy.

The aim of this study is to find out the effects of reinsurance on the performance of direct insurers in Nigeria. The study has the following objectives which include: (i) to investigate the relationship between reinsurance and underwriting profit of insurance companies, (ii) to find out the relationship between reinsurance and gross premium income of insurance companies, and (iii) to investigate the relationship between reinsurance and financial stability of insurance companies.

The authors thus make the following hypothetical propositions for the study:

Ho1: There is no significant relationship between reinsurance and gross premium income of insurance companies in Nigeria;

Ho2: There is no significant relationship between reinsurance and underwriting profit of insurance companies in Nigeria;

Ho3: There is no significant relationship between reinsurance and financial stability of insurance companies in Nigeria.

\section{LITERATURE REVIEW}

A number of works have made reference to the importance of reinsurance in a nation's insurance market as well as in the larger economy. Although insurance companies manage the risks of other businesses, they also have to mull over the optimal handling of risks, which can be done through reinsurance (Iqbal \& Rehman, 2014a). Studies reveal that insurers go through some levels of financial risk in the area of underwriting, investment and reinsurance portfolio. It has been shown that insurers are suggested to a harsh environment once engaged in high-level risk taking that have the potentials to weaken their financial ability to settle claims and thus 
threaten their survival, and without returns on their investment, insurance companies find it difficult to profit from the business of insurance (Lin, Yu \& Peterson, 2015; Yang, 2015). It is believed that reinsurance contracts can provide some levels of protections for ceding companies against the risk of their own default, especially during financial turbulence hence reinsurance providers are said to be knowledgeable in risk management skills, which could assist cedants recovering from adverse experience (Cummins, Feng \& Weiss, 2012). Those authors are of the opinion that when there exists an unhealthy hedge in the expected value between asset and liability, deepening reinsurance utilization can assist insurers' solvency in being able to assume greater risk taking on the side of asset investment.

Insurance policyholders face contractual performance risks in that after premium payments, policyholders are uncertain whether future claims on their policy will be honoured quickly and in full by the ceding company (Froot, 2007). In one of the recent works on reinsurance, Park \& Xie (2014) found out that the tendency of a primary underwriter's downgrade enhances with its reinsurance default in risk exposure from identical reinsurers, and that adverse influence also spills over to primary underwriters that have no direct exposure to the credit risks of downgraded reinsurers. Also purchasing reinsurance has been found to reduce the insolvent risk of ceding companies by stabilizing loss experience, confining liability with respect to specific risks, improving underwriting capacity, and safeguarding against catastrophes (Cummins, Dionne, Gagné \& Nouira, 2008). Reinsurance, according to Irukwu (1980), is a function expected of a professional reinsurer in the form of the provision of reinsurance protection to the primary insurer. By reinsuring all risks beyond its handling capacity, the ceding company is able to get rid of those risks capable of wiping off their financial resource.

The theory underpinning this study is the Corporate Demand Theory. This theory, according to Iqbal, Rehman \& Shahzad (2014), explicates the desires of a primary insurer to purchase reinsurance coverage against the risks it has assumed. Although, the core desire for demanding insurance or reinsurance coverage is risk sharing, since studies have shown that sharing risks optimally is not a singular reason for adopting reinsurance (Plantin, 2006). To this end, there is a need for risk diversification in a company's underwriting portfolio so as to curtail the chances of such companies being decimated by taking advantage of the expertise of reinsurance companies in being able to stabilize the shareholders' return (Doherty \& Tinic, 1981). The primary insurers, due to their business plight, which is pondered on risk management and its cover, oftentimes have high degree of enhanced volatility in their level of cash flows, and, therefore, have a reinsurance arrangement in order to dislodge the risks of insolvency and further reduce the cost of expected bankruptcy (Mayers \& Smith, 1990).

Insurance firms, on many occasions, are mindless of valuable gains attached with investment due to the fear of abnormality in losses that can diminish the value associated to their equity. They decline the positivism in Net Present Value (PPV) projects due to more gains accrued to the policyholders consequent upon their prior claims on the company's assets. Where a reinsurance cover has been arranged, the probable loss would be indemnifiable by an insurer, which enhances the insured 
ability to admit value-adding projects (Mayers \& Smith, 1990). As suggested in the theory of corporate finance, companies express the desire for insurance in a bid to solve the problem of under investment (Cummins, Dionne, Gagné \& Nouira, 2008). Reinsurance is arranged and treated as a specialised financing instrument, which usage ensures incremental value in the underwriting capability of ceding companies due to transfer method that empowers the primary insurer to assume lesser (Hoerger, Sloan \& Hassan, 1990).

According to Pitselis (2008), primary insurers adopt the usage of reinsurance as a means for business improvement, and thus, curtail the chances of losses in order for more business to be underwritten without an increment in its own capital. Mayers \& Smith (1990) earlier reiterated that direct insurers are often benefitted from expert services of professional reinsurers, majorly in the aspect of policy underwriting and pricing, claims adjustment, and handling of special risks. Another area of focus according to Froot (2001) is the reinsurance cost; and this may lead to the generation of insurance by the primary insurer at a higher cost. As suggested in an earlier work of Derrig \& Ostaszewski (1997), an adequate handling of corporate taxes and the attainment of the minimum solvency boundary would ensure proper reserving and asset-liability management in the insurance industry. Hoerger, Sloan \& Hassan (1990) and Adiel (1996) have established in their earlier works that reinsurance, as a mechanism and as adopted by a ceding company, helps in ceding actuarially unexpected risks to other underwriting companies. Iqbal \& Rehman (2014b) opined that reinsurance positively affects the direct insurers in that it minimises the financial statement volatility, most often in the area of profit and loss statement, and thus enhances firms' earnings.

\section{MATERIAL AND METHODS}

The research work employed a descriptive survey design. The rationale for its engagement was due to the fact that it provides the researchers a docile of pertinent aspects of the phenomena of interests and also observed what happened to sample subjects, without any attempt to manipulate them (Asika, 2008; Sekaran, 2003). The study made use of primary and secondary data. Primary data were sourced through a structured questionnaire, while secondary data were obtained from the annual reports and financial statements and published statistics of the Nigerian Insurers Association. According to the National Insurance Commission (NAICOM) website, there are fifty-six (56) registered insurance companies and two (2) reinsurance companies in Nigeria. Of the 56 insurance companies which form the population of this study, 29 are non-life companies, 15 are life companies, and 12 are composite. From this, 10 were selected consisting of four life and six non-life companies. Twenty five respondents were selected from each company giving a sample size of 250. The six non-life companies were Leadway Assurance, Axa Mansard Insurance, AIICO Insurance, Zenith Insurance, KBL Insurance, and NSIA Insurance. The four life insurance companies selected were FBN Life Insurance, Zenith Life Insurance, Mutual Benefits Life, and Royal Exchange Life Assurance. According to the figures released by NAICOM, the 10 companies selected jointly contributed about N123 billion premium income which represents about $41 \%$ of 
the total N302 billion for the entire industry in 2015. The 2014 and 2015 published financials of the selected companies were used to determine the Reinsurance Ceded Ratio (RCR), Return on Asset (ROA), Return on Equity (ROE), as well as the Ratio of Reinsurance to Policyholders Surplus (RRPHS).

One of our dependent variables is underwriting profit. Return on Assets (ROA) and Return on Equity (ROE) stand as the most recent measures of profitability adopted in various studies as a measuring instrument for underwriting profit (Brown \& Kamiya, 2012; Iqbal \& Rehman, 2014a; Kamau, 2013; Kozak, 2011). The total accounting profit of an insurance company is the sum of the underwriting profit and investment gains less income taxes (Kamau, 2013). The ratios formulas are noted below as:

$$
\begin{gathered}
R O A=\text { Profit after Taxes }(P A T) / \text { Total assets, } \\
\text { ROE = Profit after Taxes (PAT) / Shareholders equity. }
\end{gathered}
$$

The Ratio of Ceded Reinsurance (RCR) and Reinsurance Recoverables to Policyholder's Surplus (RRPHS) are the usual measures of reinsurance utilisation in that the former provides information on the size of reinsurance arrangements that transpired between ceding companies and professional reinsurers (Iqbal \& Rehman, 2014b). In this study, RCR is used as an instrument of measure for reinsurance utilisation. Similarly, Shiu (2011) described RRPHS as a dependency of a ceding company on its reinsurers and thus indicated a potential exposure to reinsurance collective problems. The term 'surplus' or 'policyholders' surplus refers to equity capital in the insurance industry, while 'recoverables' represent funds owed by reinsurers to insurance companies, consisting primarily of loss payments owed under reinsurance arrangements (Cummins \& Weiss, 2009). The authors present below the formulas for the ratios:

$$
\begin{gathered}
R C R=\text { Reinsurance Ceded }(R C) / \text { Net Premium Written }(N P W) ; \\
R R P H S=[\text { Ceded Reinsurance Recoverable }(C R R)+\text { Ceded Unearned } \\
\text { Premium }(C U P)+\text { Ceded Commission }(C C)] / \text { Policyholders'Surplus }(P H S) .
\end{gathered}
$$

Data were collected through a questionnaire, which is believed to be most appropriate for use in a study where sample for the study is widely dispersed (Babbie, 2005). Correlation analysis was used because it is appropriate to explore and test the relationships among the variables identified (Ott \& Longnecker, 2010). The variables of this study are: (i) independent variable, which is the reinsurance purchase utilisation represented by the Ratio of Ceded Reinsurance (RCR); and dependent variables, which are underwriting capacity, underwriting profitability, and financial stability. Out of the 250 copies of questionnaire distributed, 246 were found usable giving a response rate of about 98 percent. The sampling technique adopted was purposive in nature.

\section{RESULTS}

The research work employed correlation analysis to test the relationship between the variables using the statistical Package for Social Sciences (SPSS). 
When the relationship is of a quantitative nature, the appropriate statistical tool for discovering and measuring the relationship and expressing it in a brief formula is correlation (Mann \& Lacke, 2010).

Table 1. Correlation Analysis of Reinsurance Capacity and Gross Premium Written

\begin{tabular}{|l|c|c|c|c|}
\hline \multicolumn{2}{|c|}{} & $\begin{array}{c}\text { Reinsurance } \\
\text { Ceded (N'000) }\end{array}$ & $\begin{array}{c}\text { Ratio of Ceded } \\
\text { Reins to Net } \\
\text { Premium (\%) }\end{array}$ & $\begin{array}{c}\text { Gross Written } \\
\text { Premium } \\
\text { (N'000) }\end{array}$ \\
\hline \multirow{2}{*}{$\begin{array}{l}\text { Reinsurance } \\
\text { Ceded (N'000) }\end{array}$} & Pearson Correlation & 1 & 0.438 & $0.817^{* *}$ \\
\cline { 2 - 5 } & Sig. (2-tailed) & & 0.054 & 0.000 \\
\hline \multirow{2}{*}{$\begin{array}{l}\text { Ratio of Ceded } \\
\text { Reins to Net } \\
\text { Premium (\%) }\end{array}$} & Pearson Correlation & 0.438 & 20 & 20 \\
\cline { 2 - 5 } & Sig. (2-tailed) & 0.054 & 1 & 0.082 \\
\hline \multirow{2}{*}{$\begin{array}{l}\text { Gross Written } \\
\text { Premium } \\
(\mathbf{N} \text { (000) }\end{array}$} & Pearson Correlation & $0.817 * *$ & 0.082 & 0.731 \\
\cline { 2 - 5 } & Sig. (2-tailed) & 0.000 & 0.731 & 20 \\
\cline { 2 - 5 } & $\mathbf{N}$ & 20 & 20 & 20 \\
\hline
\end{tabular}

** - Correlation is significant at the 0.01 level (2-tailed).

Table 1 implies that the results of the correlation analysis between reinsurance capacity and gross premium written is 0.817 , where reinsurance ceded is correlated with the gross premium written, indicating a high positive correlation between the two variables. Therefore, this study rejects the null hypothesis at the 0.01 level of significance, meaning that there is a significantly positive relationship between reinsurance capacity and gross written premium. Similarly, when the ratio of ceded reinsurance to net premium is correlated with the gross premium written, the result is $r$ value of 0.438 , which is equally a positive relationship. The results, therefore, show that there is a significant relationship between reinsurance capacity and gross premium written of insurance companies in Nigeria. In consistence with the work of International Association of Insurance Supervisors (2014), allowing reinsurers to accurately price and manage the risks covered by the reinsurance contract, ceding companies must disclose information about their underwriting portfolio.

Table 2. Correlation Analysis of Reinsurance Capacity and Profitability

\begin{tabular}{|c|c|c|c|c|}
\hline \multicolumn{2}{|c|}{} & $\begin{array}{c}\text { Reinsurance } \\
\text { Ceded (N'000) }\end{array}$ & $\begin{array}{c}\text { Return On } \\
\text { Equity (\%) }\end{array}$ & $\begin{array}{c}\text { Profit After } \\
\text { Tax (N'000) }\end{array}$ \\
\hline \multirow{2}{*}{$\begin{array}{c}\text { Reinsurance } \\
\text { Ceded (N'000) }\end{array}$} & Pearson Correlation & 1 & 0.321 & $0.617 * *$ \\
\cline { 2 - 5 } & Sig. (2-tailed) & & 0.168 & 0.004 \\
\hline \multirow{2}{*}{$\begin{array}{c}\text { Return on } \\
\text { Equity (\%) }\end{array}$} & N & 20 & 20 & 20 \\
\cline { 2 - 5 } & Sig. (2-tailed) & 0.168 & 1 & $0.672 * *$ \\
\hline
\end{tabular}




\begin{tabular}{|c|c|c|c|c|}
\hline \multicolumn{2}{|c|}{} & $\begin{array}{c}\text { Reinsurance } \\
\text { Ceded (N'000) }\end{array}$ & $\begin{array}{c}\text { Return On } \\
\text { Equity (\%) }\end{array}$ & $\begin{array}{c}\text { Profit After } \\
\text { Tax (N'000) }\end{array}$ \\
\hline & N & 20 & 20 & 20 \\
\hline \multirow{3}{*}{$\begin{array}{c}\text { Profit After } \\
\text { Tax (N'000) }\end{array}$} & Pearson Correlation & $0.617^{* *}$ & $0.672 * *$ & 1 \\
\cline { 2 - 5 } & Sig. (2-tailed) & 0.004 & 0.001 & \\
\cline { 2 - 5 } & N & 20 & 20 & 20 \\
\hline
\end{tabular}

$* *-$ Correlation is significant at the 0.01 level (2-tailed).

The second hypothesis, H02, implies that there is no significant relationship between reinsurance capacity and underwriting profit of insurance companies in Nigeria. Table 2 gives $r$ values of 0.321 and 0.617 when the reinsurance ceded (RCR) was correlated with return on equity (ROE) and profit after tax (PAT) respectively. These results evidence a moderate positive correlation between the reinsurance ceded (RCR) and return on equity (ROE), and a high positive correlation between the reinsurance ceded (RCR) and profit after tax (PAT). Hence the null hypothesis is rejected at the 0.01 level of significance; it therefore indicates that there is a significantly positive relationship between reinsurance capacity and profitability of insurance companies in Nigeria. An earlier remark by Lelyveld, Liedorp \& Kampman (2009) noted that reinsurance companies enhance the overall underwriting capacity by freeing up the capital of primary insurers tied up to cover the risk. In consistence with the earlier opinions of the Group of Thirty (2006) and Plantin (2006), reinsurance offers services such as technical advice on underwriting and financial analysis, and thus, provides effective monitoring of ceding companies.

Table 3. Correlation Analysis of Reinsurance Capacity on Policyholders Surplus

\begin{tabular}{|c|c|c|c|c|}
\hline \multicolumn{2}{|c|}{} & $\begin{array}{c}\text { Reinsurance } \\
\text { Ceded (N'000) }\end{array}$ & $\begin{array}{c}\text { Ratio of Ceded } \\
\text { Reins to Net } \\
\text { Premium (\%) }\end{array}$ & $\begin{array}{c}\text { Policyholders } \\
\text { Surplus } \\
\text { (N'0000) }\end{array}$ \\
\hline \multirow{3}{*}{$\begin{array}{c}\text { Reinsurance } \\
\text { Ceded (N'000) }\end{array}$} & Pearson Correlation & 1 & 0.438 & $0.719^{* *}$ \\
\cline { 2 - 5 } & Sig. (2-tailed) & & 0.054 & 0.000 \\
\hline \multirow{2}{*}{$\begin{array}{c}\text { Ratio of Ceded } \\
\text { Reins to Net } \\
\text { Premium (\%) }\end{array}$} & Pearson Correlation & 0.438 & 20 & 20 \\
\cline { 2 - 5 } & Sig. (2-tailed) & 0.054 & 1 & 0.348 \\
\hline \multirow{2}{*}{$\begin{array}{c}\text { Policyholders } \\
\begin{array}{c}\text { Surplus } \\
\text { (N'0000) }\end{array}\end{array}$} & Pearson Correlation & $0.719^{* *}$ & 0.348 & 0.133 \\
\cline { 2 - 5 } & Sig. (2-tailed) & 0.000 & 0.133 & 20 \\
\cline { 2 - 5 } & $\mathbf{N}$ & 20 & 20 & 1 \\
\hline \multirow{2}{*}{ N } & 20 & 20 & 20 \\
\hline
\end{tabular}

** - Correlation is significant at the 0.01 level (2-tailed).

The third hypothesis, H03, implies that there is no significant relationship between reinsurance and financial stability of insurance companies in Nigeria. Table 3 gives an ' $r$ ' value of 0.719 and 0.133 when correlated reinsurance ceded and the ratio of ceded reinsurance to net premium respectively against the 
policyholders' surplus. Hence, the null hypothesis is rejected at the 0.01 level of significance; this implies that there is significant relationship between reinsurance capacity and financial stability of insurance companies in Nigeria. Earlier remark by Polonchek \& Miller (1999) opined that high monitoring costs are experienced once investors holding the securities of a reinsurance company are relatively uninformed about the quality of the financial portfolio of the insurance company. International Association of Insurance Supervisors (2014) suggests that large reinsurance groups are likely to absorb even a fat tail combining severe catastrophic and financial market stress. It was further stressed that primary insurer is covered by the reinsurance capacity with respect to the amount of capital effectively available for insurance activities rises.

\section{CONCLUSION}

The importance of insurance in a nation's economy has been affirmed in a number of studies. Its value in modern society is that of ensuring the possibilities of several economic activities in conjunction with its contributory link to the economies in the area of size, assets, and employment. Specifically, insurance contributes to the economy by promoting financial stability and reducing anxiety, substituting for government security programs, facilitating trade and commerce, and mobilising savings. This work attempts to examine the link between the level of reinsurance usage and underwriting performance of insurance companies in Nigeria. Our results show that there is a strong positive relationship between reinsurance capacity and gross written premium of insurance companies in Nigeria. Reinsurance provides an insurance company with capacity to compete against other insurance companies in a market where size would be a significant virtue. The size of a company is an attraction to insurance intermediaries in placing their clients' insurance business. Also, using Returns on Assets (ROA) and Returns on Equity (ROA), the empirical results from the correlation analysis provide evidence that reinsurance utilisation has a positive effect on the profitability of direct insurers. In addition, the results equally showed that purchasing reinsurance reduces insurers' insolvency risks and increases the financial stability of insurance companies by creating stable loss situation, capacity enhancement and minimising cost from specific risks, and offering protection against catastrophes.

Based on the findings of this work, it is recommended that reinsurance facilities be given adequate attention by insurance companies. Rather than see reinsurance as a cost centre, insurance executives should view it as an important risk management mechanism. The contributory knowledge derived in this study provides theoretical and indepth explanation on the relationship between reinsurance utilisation and insurance company's performance in Nigeria, an area that has been largely ignored in research. Since only two-year financials were used for this study, it is suggested that further studies be carried out using the data of several years. 


\section{REFERENCES}

Adiel, R. (1996). Reinsurance and the management of regulatory ratios and taxes in the property-casualty insurance industry', Journal of Accounting and Economics, 22(1-3), 207-240.

Asika, N. (2008). Research methodology in the behavioural sciences. Lagos: Longman Nigeria Plc.

Babbie, E. (2005). The basic of social research ( $3^{\text {rd }}$ edn). Canada: Thomson Learning Inc.

Browne, M. J., \& Kamiya, S. (2012). A Theory of the Demand for Underwriting. The Journal of Risk and Insurance, 79(2), 335-349. Retrieved from http://www.aria.org/rts/proceedings/2010/Demandfor Underwriting_Browne and Kamiya.pdf

Cummins, J. D., Dionne, G., Gagné, R., \& Nouira, A. (2008). The Costs and Benefits of Reinsurance. Cahier de recherche no IEA-08-04. Retrieved from http://www.hec.ca/iea/cahiers/2008/iea0804_rgagne.pdf

Cummins, J. D., \& Weiss, M. A. (2009). Convergence of insurance and financial markets: hybrid and securitized risk-transfer solutions. Journal of Risk and Insurance, 76(3), 493-545. https://doi.org/10.1111/j.1539-6975.2009.01311.x

Cummins, J. D., Feng, Z., \& Weiss, M. A. (2012). Reinsurance counterparty relationships and firm performance in the US property-liability insurance industry. Working paper, Temple University, Philadelphia, PA

Derrig, R. A., \& Ostaszewski, K. M. (1997). Managing the tax liability of a property-liability insurance company. Journal of Risk and Insurance, 64(4), 695-711. Retrieved from https://www.math.illinoisstate.edu/Krzyysio/Derr-Ost1997JRI-Tax.pdf

Doherty, N. A., \& Tinic, S. M. (1981). A note on reinsurance under conditions of capital market equilibrium. Journal of Finance, 36, 949-953. https://doi.org/10.1111/j.1540-6261

Fatula, O. (2007). The imperative of recapitalization and consolidation in the Nigerian insurance industry. Ikeja Bar Review, 128.

Froot, K. A. (2001). The market for catastrophe risk: a clinical examination. Journal of Financial Economics, 60(2-3), 529-571. Retrieved from https://doi.org/10.1016/S0304-405X(01)00052-6

Froot, K. A. (2007). Risk management, capital budgeting, and capital structure policy for insurers and reinsurers. The Journal of Risk and Insurance, 74(2), 273-299. https://doi.org/10.1111/j.15396975.2007.00213.x

Garven, J. R., Hillard, J. I., \& Grace, M. F. (2014). Adverse selection in reinsurance market. Working paper, Georgia State University. https://doi.org/101057/grir.2014.13

Group of Thirty. (2006). Reinsurance and international financial markets. Washington: Group of Thirty. Retrieved from https://www.group30.org

Hall, M. A. (2010). Government-Sponsored Reinsurance, 19 Annals Health L. 465 (2010). Retrieved from http://lawecommons.luc.edu/annals/vol19/iss3/4

Hoerger, T. J., Sloan, F. A., \& Hassan, M. (1990). Loss volatility, bankruptcy, and the demand for reinsurance. Journal of Risk and Uncertainty, 3(3), 221-245. https://doi.org/10.1007/BF00116782

International Association of Insurance Supervisors. (2012). Reinsurance and financial stability. Basel: IAIS. Retrieved from https://www.iaisweb.org

Iqbal, H. T., \& Rehman, M. U. (2014a). Reinsurance analysis with respect to its impact on the performance: Evidence from non-life insurers in Pakistan. The IEB International Journal of Finance, 8, 90-113. https://doi.org/10.1505/IJFMS.2014.063946

Iqbal, H. T., \& Rehman, M. U. (2014b). Empirical analysis of reinsurance utilisation and dependency with respect to its impact on the performance of domestic non-life stock insurance companies operating in the private sector of Pakistan. International Journal of Financial Services Management, 7(2), 95-112. Retrieved from https://doi.org/10.1504/IJFSM.2014.063946

Iqbal, H. T., Rehman, M. U., \& Shahzad, S. J. H. (2014). Analysis of Change in Profitability due to Reinsurance Utilization and Leverage Levels: Evidence from Non-Life Insurance Sector of Pakistan. JISR-MSSE, 12(1). Retrieved from https://www.researchgate.net/publication/273120322

Irukwu, J. O. (1980). Reinsurance in the Third world. Ibadan: the Caxton Press (West Africa).

Jirsarael, S. R., Kalantari, H., Kalantari, D., Jalah, R., \& Nozari, K. (2013). Reinsurance and its impact on risk management. Arabian Journal of business and management review, 2(6), 223-229. Retrieved from https://www.arabianjbmr.com/pdfs/OM_Vol_2_(6)/26.pdf

Kamau, M. H. (2013). The relationship between underwriting profit and investment income for the general insurance industry in Kenya (Master's thesis). University of Nairobi, Kenya.

Kozak, S. (2011). Determinants of profitability of non-life insurance companies in Poland during integration with the European financial system. Electronic Journal of Polish Agricultural Universities, 14(1), 1-14. Retrieved from https://www.ejpau.media.pl

Lelyveld, I. V., Liedorp, F., \& Kampman, M. (2009). An empirical assessment of reinsurance risk. DNB Working Paper, No. 201/ January, Amsterdam. Retrieved from https://www.dnb.nl/binaries/Working\%20paper\%20201_tcm46-212957.pdf 
Lin, Y., Yu, J., \& Peterson, M. O. (2015). Reinsurance network and their impact on reinsurance decisions: Theory and empirical evidence. Journal of Risk and Insurance, 82(3), 531-569. https://doi.org/10.1111/jori.12032

Mann, P. S. \& Lacke, C. J. (2010). Introductory statistics ( $7^{\text {th }}$ ed.). USA: John Wiley \& Sons, Inc. Retrieved from https://archive.org/details/introductoryStatistics7thEdP.MannWilley2010WW

Mayers, D., \& Smith, C. W. (1990). On the corporate demand for insurance: evidence from the reinsurance market. The Journal of Business, 63(1), 19-40. Retrieved from http://www.jstor.org/stable/2353235

Naidoo, K. (2010). Strategies for Advancing the Growth and Development of the Nigerian Insurance Industry. Retrieved from http://www.saia.co.za/info-center/saia-documents/archive/archives-various-dat/positionpaper-strat.pdf

Oke, O. (2012). Insurance sector development and economic growth in Nigeria. African Journal of Business Management, 6(23), 7016-7023. https://doi.org/10.5897/AJBM11.2853

Oluoma, R. O. (2014). Impact of insurance market activity on economic growth in Nigeria (Doctoral thesis), University of Nigeria, Nsukka, Nigeria. Retrieved from http://hdl.handle.net/123456789/3684

Ott, R. L. \& Longnecker, M. (2010). An introduction to statistical method and data analysis. $\left(6^{\text {th }} e d\right.$.). Belmont: Cengage Learning. Retrieved from http://www.univpgri-palembang.ac.id/perpusfkip/Perpustakaan/Metodologi/Lyman_Ott,_Michael_Longnecker-

An_Introduction_to_Statistical_Methods_and_Data_Analysis,_6th_Edition___Brooks_Cole(2010).pdf

Park, S. C. \& Xie, X. (2014). Reinsurance and systemic risk: The impact of reinsurer downgrading on propertycasualty insurers. Journal of Risk and Insurance, 81(3), 587-622. https://doi.org/10.1111/jori.12045

Pitselis, G. (2008). An overview on solvency supervision, regulations and prediction of insolvency. Belgian Actuarial Bulletin, 8(1), 37-53. Retrieved from https://www.iabe.be/sites/default/files/bijlagen/vol4.5pitselis-O.pdf

Plantin, G. (2006). Does reinsurance need reinsurance? The Journal of Risk and Insurance, 73(1), 153-168. https://doi.org/10.1111/j.1539-6975.2006.00169.x

Polonchek, J. \& Miller, R. K. (1999). Contagion effects in the insurance industry. The Journal of Risk and Insurance, 66(3), 459-475. https://doi.org/10.2307/253556

Rewane, B. (2015). Growth options for insurance business in Nigeria. 2015 Insurance Industry Mega Conference, IICC, July 27, 2015 in Lagos.

Sekaran, U. (2003). Research methods for business: A skill-building approach ( $4^{\text {th }}$ edn). USA: John Wiley \& Sons, Inc.

Shah, A., Wilcox, R., \& Alip, A. (2015). Insurance regulation for sustainable development. The University of Cambridge Institute for Sustainability Leadership. Retrieved on March 22, 2017, from http://www.cisl.cam.ac.uk/publications/publication-pdfs/insurance-regulation-report.pdf

Shiu, Y. M. (2011). Reinsurance and capital structure: Evidence from the United Kingdom non-life Insurance Industry. The Journal of Risk and Insurance, 78(2), 475-494. https://doi.org/10.1111/j.15396975.2010.01387.x

Yang, S. (2015). Insurers' underwriting result and investment risk-taking behaviour - evidence from US property and casualty insurance industry. World Risk and Insurance Economic Congress Munich, Germany, August 2-6, 2015. Retrieved on February 2, 2017 from http://www.wriec.net/wpcontent/uploads/2015/07/3F3_Yang.pdf

Yinusa, O. \& Akinlo, T. (2013). Insurance development and economic growth in Nigeria, 1986-2010. Journal of Economics and International Finance, 5(5), 218-224. https://doi.org/10.5897/JEIF2013.0498

\section{AUTHORS' SHORT BIOGRAPHIES}

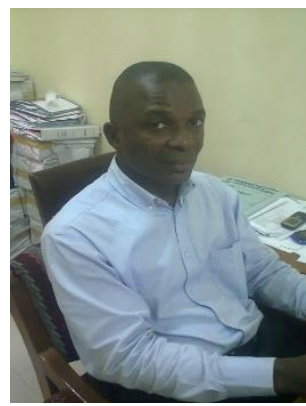

Sunday Adekunle ADULOJU (Ph.D.) holds the Bachelor's degree in insurance (University of Lagos, Nigeria), the M.S. degree in business administration (University of Lagos, Nigeria), the M.S. degree in marketing (University of Lagos, Nigeria), and the Ph.D. degree in business administration (University of Lagos, Nigeria). His research interests include insurance and risk management, insurance marketing, motor insurance, reinsurance, and property and liability insurance. He is a seasonal Lecturer with many years of teaching experience at the Department of Actuarial Science and Insurance, University of Lagos, Akoka, Lagos, Nigeria. His research articles have been published in recognized local and international journals.

Address: University of Lagos, Faculty of Business Administration, Department of Actuarial Science and Insurance, Nigeria.

E-mail(s): ksaduloju@yahoo.com, saduloju@unilag.edu.ng 


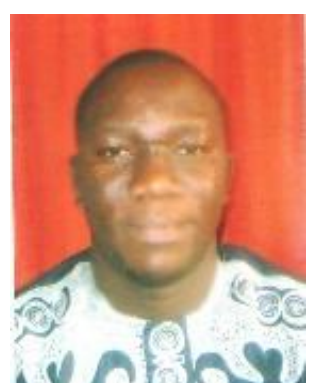

Sunday Stephen AJEMUNIGBOHUN holds the Bachelor's degree in insurance (Lagos State University, Nigeria), the M.S. degree in business administration (University of Lagos, Nigeria), the M.S. degree in risk management and insurance (University of Lagos, Nigeria), and the M.Phil. degree in risk management and insurance (University of Lagos, Nigeria). $\mathrm{He}$ is currently a Ph.D. student in risk management and insurance at the University of Lagos, Nigeria. His research interests include transportation insurance, reinsurance, insurance claims management, health insurance, insurance marketing, and business risk management. He is a seasonal Lecturer with many years of teaching experience at the Department of Insurance, Lagos State University, Ojo, Lagos, Nigeria. His publications can be found in both scholarly domestic and international journals. He has been found worthy to be a Member of renowned professional institutes, such as Chartered Insurance Institute of Nigeria (CIIN) and the Institute of Strategic Management of Nigeria (ISMN).

Address: Lagos State University, Faculty of Management Sciences, Department of Insurance, Badagry Expressway, Nigeria.

E-mail(s): insurancelecturerlasu2009@yahoo.com, sundayajemunigbohun@lasu.edu.ng, insuranceprofessorlasu@gmail.com 